\title{
Dynamic and Analysis of A Geo-Polymer Concrete Structure
}

\author{
P.Suresh Chandra ${ }^{1}$, C.E.Jessie Monica ${ }^{2}$ \\ ${ }^{I}$ Assistant Professor, Department of Civil Engineering, Malla Reddy Engineering College, Telangana, India \\ ${ }^{2}$ Department of Civil Engineering, Malla Reddy Engineering College, Telangana, India \\ E-mail: ${ }^{1}$ psuresh235@gmail.com, ${ }^{2}$ chirgurijessiemonica@gmail.com
}

\begin{abstract}
The standard portland cement (OPC) was traditionally used as the binding agent in concrete. However it is also important to find alternative emissionsfree concrete binding agents to reduce environmental damage caused by cement manufacturing. Geopolymers, also known as inorganic polymers, use byproducts like fly ash rather than cement. Recent studies have shown that geopolymer concrete based on fly ash has enough properties for use. As the geopolymer strength mechanism is different from the OPC binder, an appropriate constituent model for geopolymer concrete must be obtained in order to predict the load-deflection behavior and strength of geopolymer concrete structural components. A number of problems faced with today's cement industry are addressed by geopolymer binders. These binders have similar or better engineering qualities in comparison with cement and can use many types of waste materials.

This project describes the seismic analysis of buildings with high-rise structures, the model of residential $\mathbf{G + 1 0}$ buildings with traditional concrete and geopolymer concrete properties is modelled and analysis is carried out using the response spectra method considering the position of the building in zone III, this analysis would generate the effect of higher vibration modes and real force distribution in elastic range. Test results include maximum story shifts, maximum story drifts, story shears and story stiffness, and an efficient lateral load resistance system, helping to establish whether geo-polymer concrete can be used in high-rise building construction as dynamic loads are included in the high-rise structures
\end{abstract}

Keywords: Geo-Polymer Concrete, ETABS 2016 software, Response Spectra

\section{Introduction}

\subsection{Introduction:-}

Earthquakes are very popular these days in nature for many reasons. Instead, we don't discuss why the earthquake is but how to cope with the burden of the earthquake in structures or buildings. This is the most important criteria for us because the earthquakes become very frequent to us, particularly in the case of high-rises buildings it is impossible to design a safer building or analyze the buildings in general regular form using static loads such as live loads, dead loads etc, The dynamic analysis and modeling the necessary structure using ETABS software is not sufficient and therefore the structure in the ETABS is analyzed with the response spectra process.

\subsection{Geo- Polymer Concrete:-}

Geopolymer concrete is an advanced and environmentally friendly construction material and an alternative to cement concrete in Portland. The utilization of geopolymers has lowered demand for Portland cement with heavy emissions of $\mathrm{CO} 2$. Geopolymer has been named after materials found by Daidovits in 1978 via chains or networks or inorganic molecules. Geopolymer cement concrete consists of waste material, fly ash and granular soil furnace slag (GGBS). The waste product generated by the thermal power plant is Fly Ash. Fly Ash is a stainless steel waste material. Both fly ash and GGBS are treated with sufficient technologies and used in concrete construction as geopolymer concrete. Through using this concrete the inventories of waste are reduced, and by decreasing Portland cement demand, carbon emissions are reduced. The key component of silicone and aluminum source geopolymers supplied by thermalactivated natural materials (for example kaolinite) or industrial byproducts (for example, fly ash, or plates) and an alkaline activation solution that polymerizes these materials into molecular chains and networks for the production of hardened binders. Often called inorganic cement or cement with alkaline activation.

\subsection{Response Spectra:-}

The plot is calculated by a series of oscillators of different natural frequencies, causing them to travel through the same base vibration, i.e. the move, velocity and acceleration (OR) It represents the continuum of maximal response during an idealized one-degree system with different natural cycles and given damping during a given earthquake ground motion.This is the most useful term in earthquake engineering and in applying seismological principles to the design of the structure by the powerful earthquake. In the case of the response continuum, the time differences in the response range are not taken into account, but the extreme value transmits the critical details relating to maximum powers, maximum displacement and maximum deformation, which must be capable of sustaining. 


\section{Methodology}

All the designs are designed to show both the vertical and lateral strength and rigidity needed for the structural efficiency and the acceptability deformity defined by the governing code of building for the seismic and seismic loads combined effects. Due to its safety factor, most structures appear to be adequately shielded from vertical shaking, in particular because of the design specification. In structures with wide spans, where stability for the design or the overall stability analysis for structures, vertical acceleration should be considered too.

In general, the majority of provisions on earthquake codes suggested that the structures would resist:-

- Minor damage-free earthquake.

- Mild earthquakes and certain non-structural accidents with minimal structural damage.

- Majors earthquake and non-structural disruption without collapse.

- It is expectable, in certain structural members, that the structure can undergo a reasonably highdeformation.

The seismic codes apply to a specific country or region. The core code that provides for the measurement of seismic design forces in India is IS 1893:2002 (part 1.). This force is conditioned by a seismic coefficient, and the structural mass of the structure, and then by characteristics such as the seismic field, structural importance, rigidity, soil and ductiles. In IS 1893:2002 the calculation of seismic stresses for various structures and buildings is addressed (part 1).

The estimation of the base shear and the distribution of its height. The study may be carried out by external intervention, structural or structural material behavior and the chosen structural mode form. In all these instances, the system is discreet and the mass is contained in floors, which comprise the top and bottom of half of the column and walls. Furthermore, it also lumps in live loads on this floor.

Seismic analysis of the structure is important to determine seismic responses. Depending on the type of external action and the behavior of the structure, this review can further be defined as:

- Linear Static Evaluation

- Equivalent static analysis

- Linear Functional Analysis

- Answer to spectrum

- Linear History Review

- Non-linear static analyzing

- Drive over research

- Dynamics non-linear analysis.

- Nonlinear time history review

- Linear static analysis or static equivalent approach can be used for regular limited-height structures.

Dynamic linear analyzes can be conducted with a spectrum response approach. Intensity degree and its distribution in the structural height is the major difference between linear static and linear dynamic studies. The inelastic comportement of the system over linear, static or dynamic analyses is enhanced by nonlinear static analysis. A nonlinear dynamic analysis is the only way of understanding the real actions of an organization during an earthquake. In the direct numerical integration of differential motion equations the method is based on the elasto-plastic distortion of the structural component.

\section{Modelling}

Analysis data:-

\begin{tabular}{|c|l|l|}
\hline $\mathbf{1}$ & Details of the building & OMRF \\
\hline i) & Structure & G+10 \\
\hline ii) & Number of stories & Regular and Symmetrical in plan \\
\hline iii) & Type of building & $10.5 \mathrm{~m} \times 14.5 \mathrm{~m}$ \\
\hline iv) & Plan area & $33 \mathrm{~m}$ \\
\hline v) & Height of the building & Fixed \\
\hline vi) & Support & III \\
\hline vii) & Seismic zones & \\
\hline $\mathbf{2}$ & Material properties & $\mathrm{M} 30$ \\
\hline i) & Grade of concrete & Fe415 \\
\hline ii) & Grade of steel & $25 \mathrm{kN} / \mathrm{m} 3$ \\
\hline iii) & Density of reinforced concrete & $27386.13 \mathrm{KN} / \mathrm{m} 2$ \\
\hline iv) & Young's modulus of $M 30$ concrete, Ec & $247800 \mathrm{KN} / \mathrm{m} 2$ \\
\hline v) & Young's modulus steel, EG & 0.2 \\
\hline vi) & Poissions ration $\mu_{\mathrm{c}}$ & 0.15 \\
\hline vii) & Poissions ration ${ }_{2} \mu_{\mathrm{G}}$ & $2 \times 108 \mathrm{kN} / \mathrm{m} 2$ \\
\hline viii) & Young's modulus steel, Es & \\
\hline
\end{tabular}




\begin{tabular}{|c|c|c|c|c|}
\hline 3 & \multicolumn{4}{|c|}{ Type of Loads \& their intensities } \\
\hline i) & \multicolumn{3}{|c|}{ Floor finish } & $1.5 \mathrm{kN} / \mathrm{m} 2$ \\
\hline ii) & \multicolumn{3}{|l|}{ Live load on floors } & $2 \mathrm{kN} / \mathrm{m} 2$ \\
\hline iii) & \multicolumn{3}{|c|}{ External wall load on beams } & $11.5 \mathrm{kN} / \mathrm{m} 2$ \\
\hline iv) & \multicolumn{3}{|c|}{ Internal wall load on beams } & $5.27 \mathrm{kN} / \mathrm{m} 2$ \\
\hline 4 & \multicolumn{4}{|c|}{ Seismic Properties } \\
\hline i) & Zones & III & & 0.16 \\
\hline ii) & \multicolumn{3}{|l|}{ Importance factor ( I ) } & 1 \\
\hline iii) & \multicolumn{3}{|c|}{ Response reduction factor ( $\mathrm{R}$ ) } & $5 \%$ \\
\hline iv) & \multicolumn{3}{|c|}{ Soil type } & II \\
\hline v) & \multicolumn{3}{|l|}{ Damping ratio } & 0.05 \\
\hline vi) & \multicolumn{3}{|l|}{ Wind Speed - Zone III } & $39 \mathrm{~m} / \mathrm{sec}$ \\
\hline \multirow[t]{4}{*}{ vii) } & \multicolumn{3}{|l|}{ Wind coefficients } & \\
\hline & \multicolumn{3}{|l|}{ Terrain category } & 2 \\
\hline & \multicolumn{3}{|l|}{ Risk coefficient } & 1 \\
\hline & \multicolumn{3}{|l|}{ Topography } & 1 \\
\hline 5 & Member Properties & No. of stories & Grade & Section sizes $(\mathbf{m m})$ \\
\hline i) & Column & All & M30 & $450 \times 450$ \\
\hline ii) & Beam & All & M30 & $500 \times 230$ \\
\hline iii) & Slab & All & M30 & 175 \\
\hline
\end{tabular}

Structural models from ETABS:_Plan and 3D view of flat slab structures):

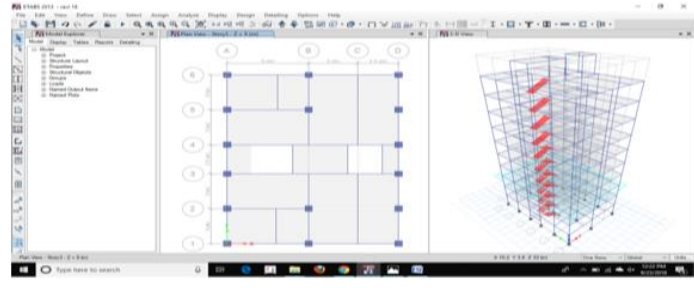

Figure 3.1 Plan and 3D view of the Structure

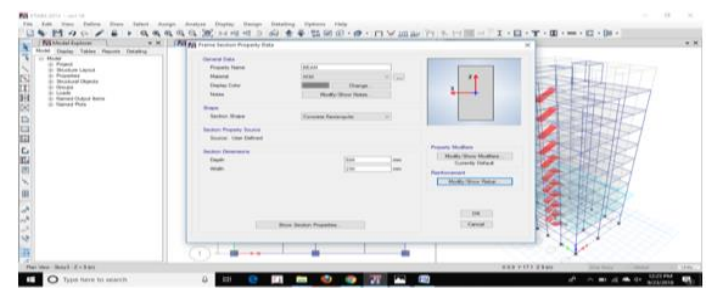

Figure 3.3 Defining of Beam

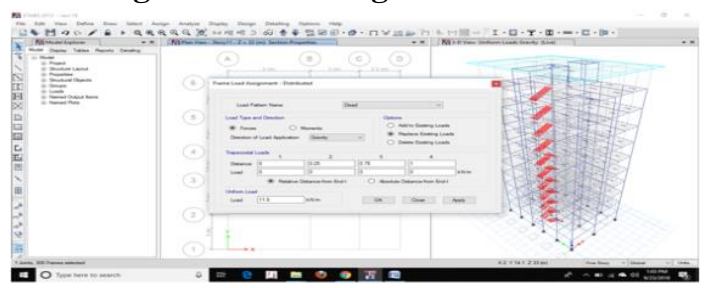

Figure 3.5 Defining Outer Wall Load

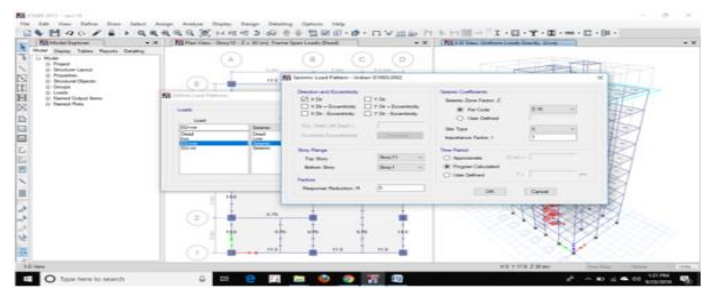

Figure 3.7 Defining the Earth Quake Load

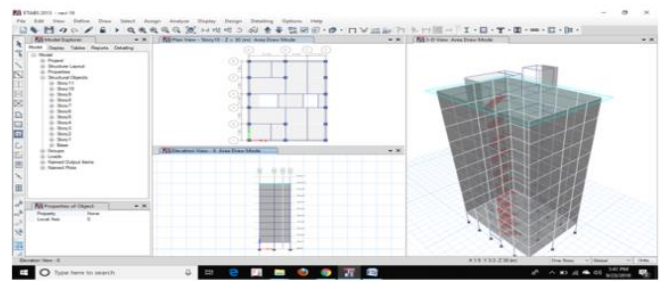

Figure 3.2 Plan, Elevation and 3D View of the structure

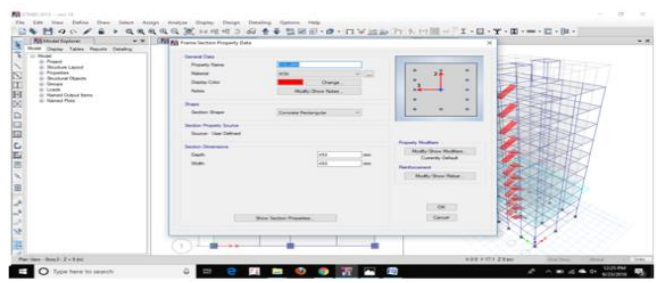

Figure 3.4 Defining of Column

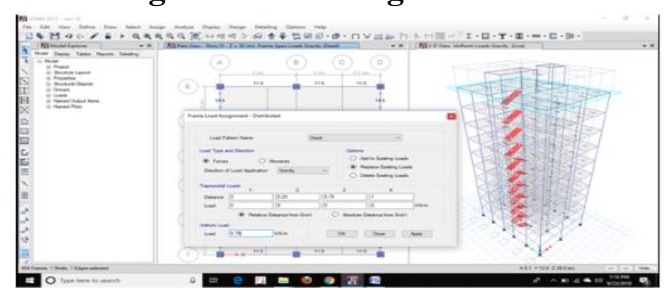

Figure 3.6 Defining Inner Wall Load

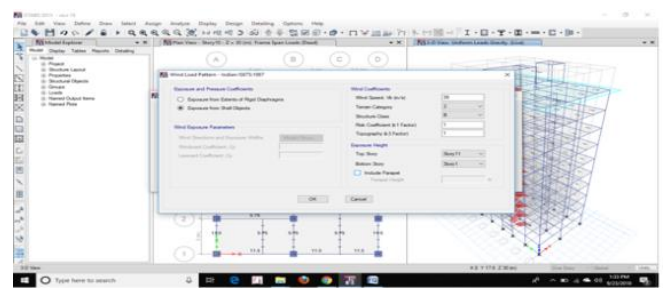

Figure 3.8Defining the Wind Load 


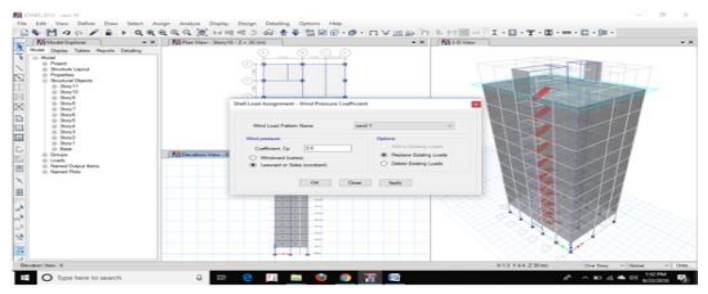

Figure 3.9 Assigning the Wind Load

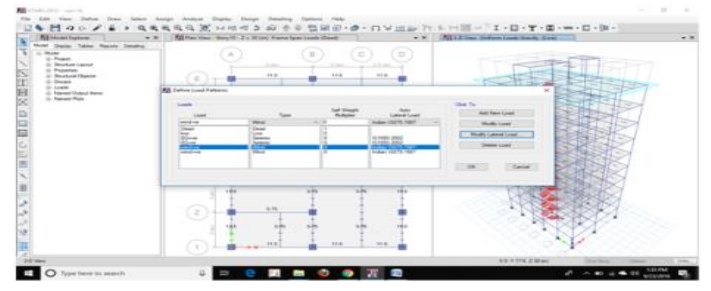

Figure 3.11 Loading Patterns

4. Results And Discussions

1. Story displacement:-

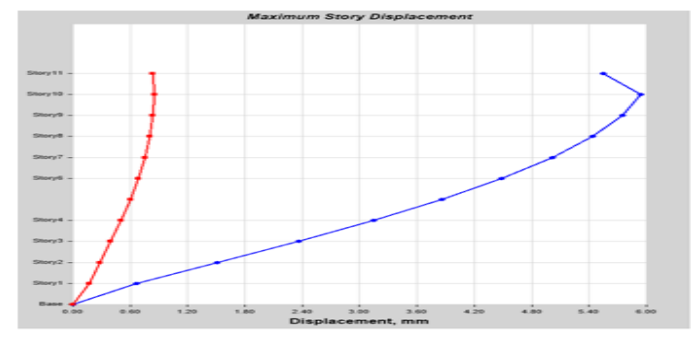

Fig 4.1 Story Displacement of conventional Concrete in zone III in X-Direction Using Response Spectrum Method

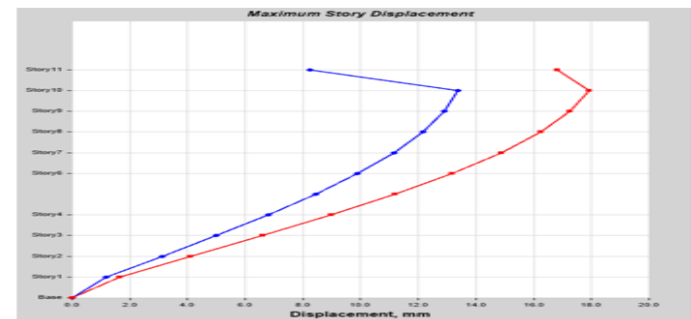

Fig 4.3 Story Displacement of conventional Concrete in zone III in Y- Direction

Using Response Spectrum Method

\section{Story drifts:-}

Story Drift is characterized as the two consecutive floors displacement ratio to the height of that building. Frame

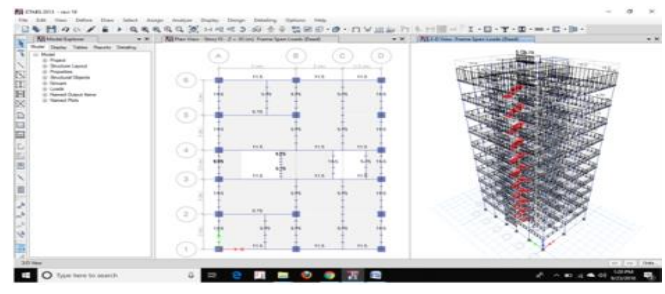

Figure 3.10 Assigning of Loads

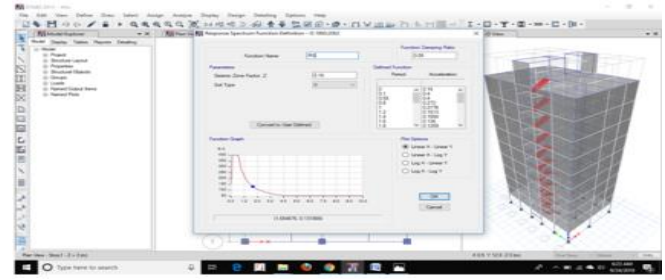

Figure 3.12 Defining Response Spectrum Data

It's the full relocation of the story from the field. The story displacement of modular structures in zone III using the $\mathrm{X}$-direction response spectrum process.

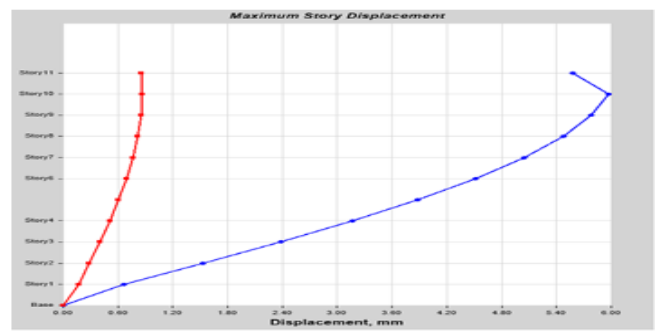

Fig 4.2 Story Displacement of Geo-Polymer Concrete in Zone III in X- Direction Using Response Spectrum Method

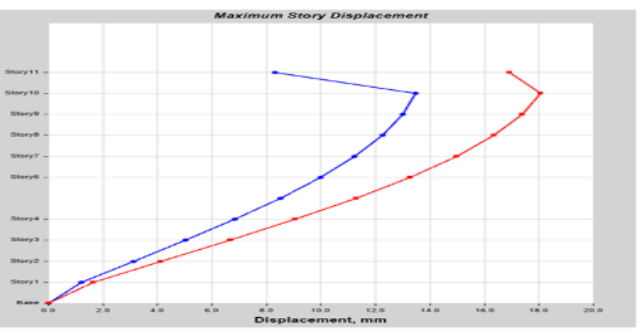

Fig 4.4 Story Displacement of Geo-Polymer Concrete in Zone III in Y- Direction

Using Response Spectrum Method

structure shortcomings are due to the contributions in flexure and shear mode. Higher axial forces and deformations in columns and their effects build-up over higher structures render bending part displacement dominant. 


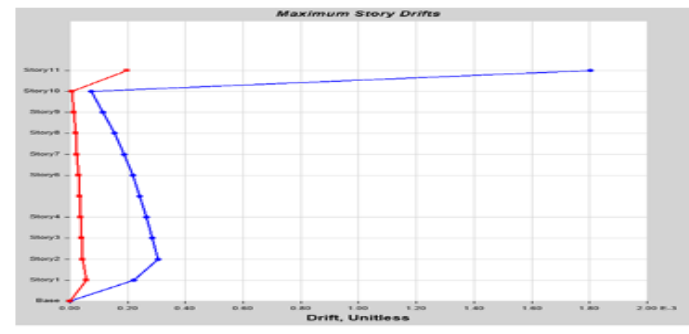

Figure 4.5 Story Drift of conventional Concrete in zone III in X-Direction Using Response Spectrum Method

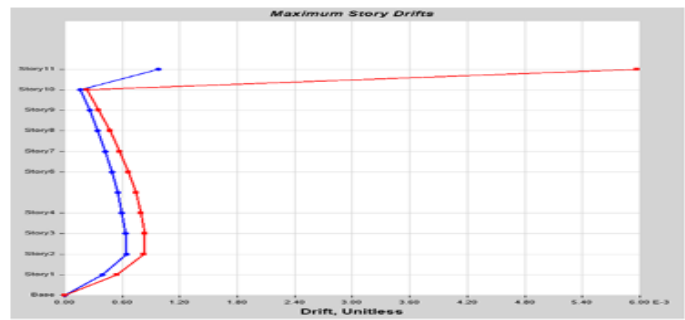

Figure 4.7 Story Drift of Modular Structures in Zone III using the Y-Direction using Response Spectrum method

\section{Story shear:-}

Base shear is an approximation of the high lateral force predicted to occur at the base of a structure due to seismic soil motions. The shaving factor is the shear strength

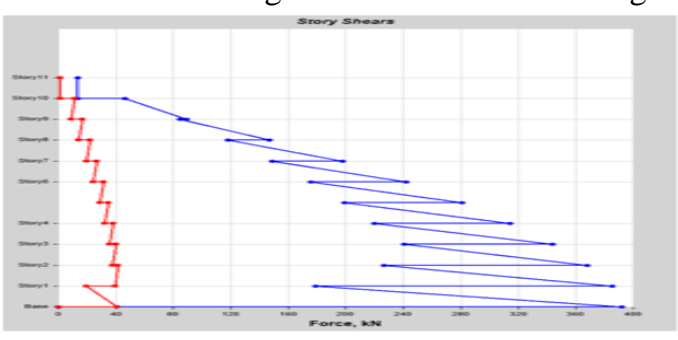

Figure 4.9 Story Shear of Conventional Concrete in zone III in X-Direction Using Response Spectrum Method

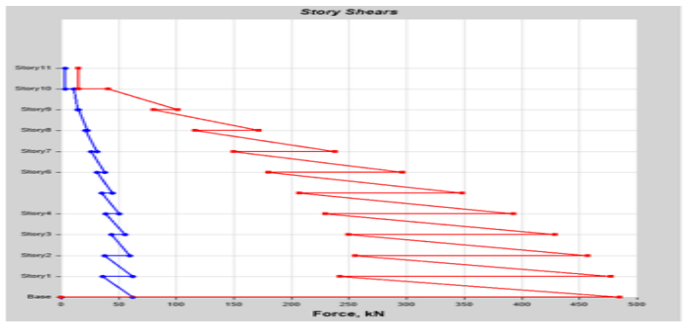

Figure 4.11 Story Shear of Conventional Concrete in zone III in Y-Direction Using Response Spectrum Method

\section{Story Stiffness:-}

In the lateral rigidity of a story Ks the proportion of story shear to story drift is generally established. When frames

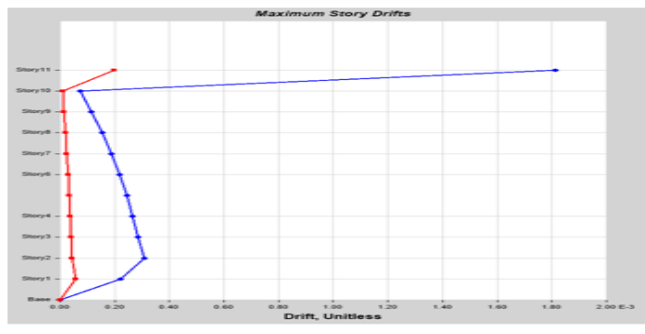

Figure 4.6 Story Drift of Geo-Polymer Concrete in Zone III in X- Direction Using Response Spectrum Method

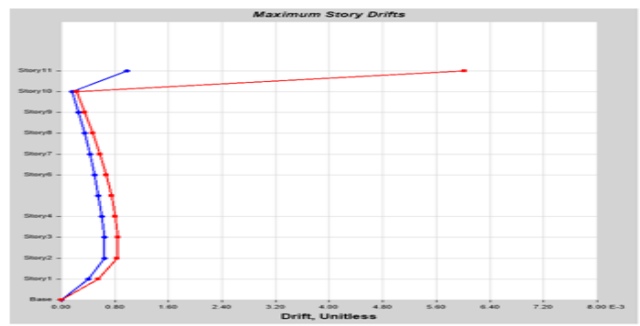

Figure 4.8 Story Drift of Geo-Polymer Concrete in Zone III using the Y-Direction using Response Spectrum Method ratio of the story when a story collapse takes place with the shear strength of the story when the complete collapse is present.

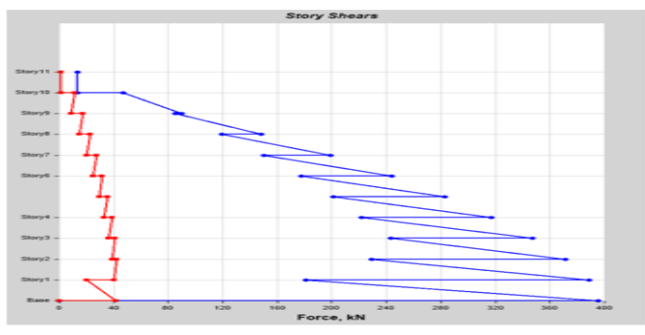

Figure 4.10 Story Shear of Geo-Polymer Concrete in zone III in X-Direction Using Response Spectrum Method

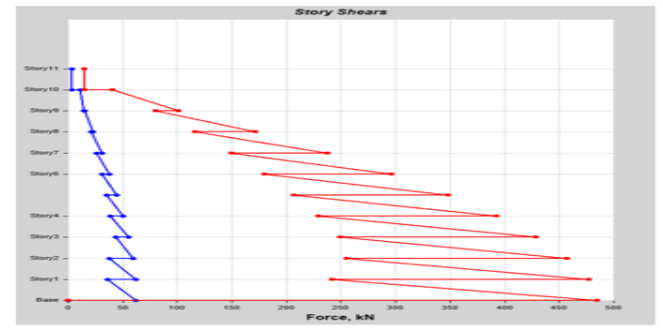

Figure 4.12 Story Shear of Geo-Polymer Concrete in zone III in Y-Direction Using Response Spectrum Method

are laterally normal, the load distributions are small enough to ignore the differences in the side rigidity of a given story in many load cells. 


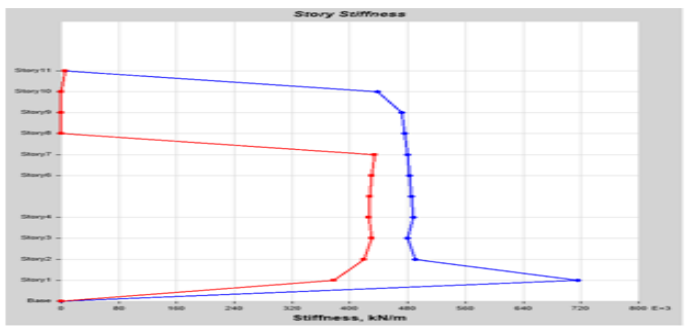

Figure 4.13 Story stiffness of Conventional Concrete in Zone III in X-Direction Using Response Spectrum Method

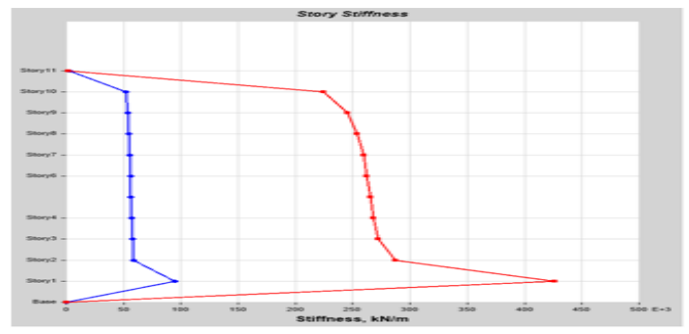

Figure 4.15 Story Stiffness of Conventional Concrete in Zone III in Y-Direction Using Response Spectrum Method

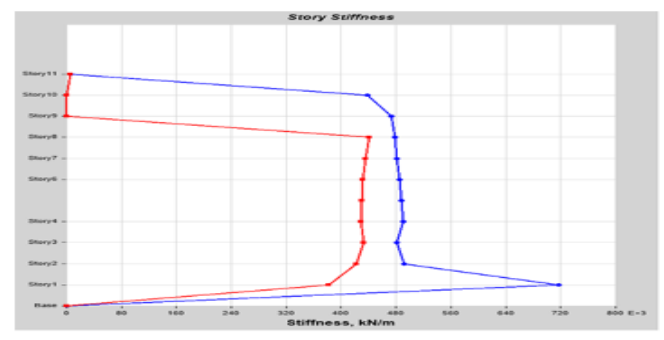

Figure 4.14 Story Stiffness of Geo-Polymer Concrete in Zone III in X-Direction Using Response Spectrum Method

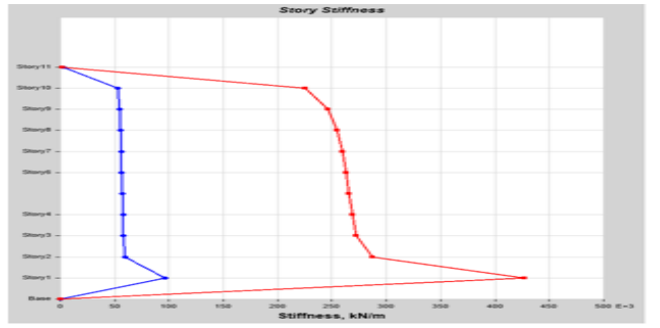

Figure 4.16 Story Stiffness of Geo-Polymer Concrete in Zone III in Y-Direction Using Response Spectrum Method

\section{CONCLUSION}

The seismic pattern behavior in seismic zone III is discussed, and seismic comportements are contrasted between a structure with traditional concrete and geopolymer concrete structure with a response continuum process i.e. displacement of the storyteller, history drifts, historical shear and history stiffness. The results of the results obtained are discussed in depth in this chapter.

The maximum change between conventional concrete and geopolymer concrete is 3.22 percent, but even when compared with conventional concrete, it can be seen that the displacement is higher at the coded limits.

READ. The overall drift in the story between traditional concrete and the geopolymer concrete is $2.7 \%$.

The maximum shear story between a traditional concrete framework and a geopolymer concrete structure, as opposed to conventional concrete, raises the shear story, which resists seismic loads as compared to conventional concrete, but we can see that we are still able to use the geopolymer structure, which is more than 2.2 percent.

The maximum stiffness of the tale between the traditional framework of concrete and the geopolymer structure is 1.64 percent.

We concluded that the structure of the tension and of traditional concrete and the spatial structure, with its built structure, could be used even though the seismic charge and the wind charge plays a large part for this in its architecture. But by using the structure of the geo-polymer concrete, it can be inexpensive, but the environmental construction can only be promoted, at that time.

\section{References}

[1] Kirtan T and Jayaramappa N, "Comparative study of multi-storey RC frame with shear wall and hexagrid system", Indian Journal of Research, Volume: 06, Issue: 01, January 2017, pp. 814-817, ISSN 2250-1991.

[2] JayeshVenkolath and Rahul Krishnan K, "Optimal diagrid angle of high-rise buildings subjected to lateral loads", International Research Journal of Engineering and Technology (IRJET), Volume: 03 Issue: 09, September 2016, (pp. 841-846).

[3] Abhinav V, Sreenatha Reddy, Vasudeva Naidu and Madan Mohan, "Seismic analysis of multi-story RC building with shear wall using STAAD.Pro", International Journal of Innovative Technology and Research (IJITR), Volume: 4, Issue: 5, August 2016, pp. 3776-3779, ISSN 2320 -5547.

[4] Nandeesh K C and Geetha K, " Comparative study of hyperbolic circular diagrid steel structure rehabilitated at core with shear wall and steel braced frames", International Journal of research in Engineering and technology (IJRET), Volume: 05, Issue: 07, July 2016, pp. 317- 323, eISSN: 2319-1163, p-ISSN: 2321-7308.

[5] Md. Samdani Azad and Syed HazniAbdGani, "Comparative study of seismic analysis of multi-story buildings with shear walls and bracing systems", International Journal of Advanced Structures and Geotechnical Engineering (IJASGE), Volume: 05, Issue: 03, July 2016 pp. 72-77, ISSN 2319-5347.

[6] HarshitaTripathi and SaritaSingla, "Diagrid structural system for RC framed multi-storey building", International Journal of Scientific \& Engineering Research (IJSER), Volume: 7, Issue: 6, June 2016, pp. 356-362, ISSN 2229-5518. 
[7] PriyankaSoni, PurushottamLalTamarkar and VikkyKumhar, "Structural analysis of multi-storey building of different shear walls location and heights", International Journal of Engineering Trends and Technology (IJETT), Volume: 32, February 2016.

[8] Shubham R Kasat, Sanket R Patil, Akshay S Raut and Shrikant R Bhuskade, "Comparative study of multistorey building under the action of shear wall using ETAB software", International Conference on Electrical, Electronics, and Optimization Techniques (ICEEOT), 2016.

[9] Alkuntel C V, Dhimate M V, Mahajan M B, Shevale S Y, Shinde S K and Raskar A, "Seismic analysis of multistorey building having infill wall, shear wall and bracing", Imperial Journal of Interdisciplinary Research (IJIR), Volume: 02, Issue: 06, 2016, pp. 1522-1524, ISSN: 2454-1362.

[10] SaketYadav and VivekGarg, "Advantage of steel diagrid building over conventional building," International Journal of Civil and Structural Engineering Research (ISSN), Volume: 03, Issue: 01, September 2015, pp. 394406.

[11] Anil Baral and Yajdani S K, "Seismic analysis of rc framed building for different positions for shear wall", International Journal of Innovative Research in Science (IJIRSET), volume: 04, Issue: 05, May 2015, pp. 33463353, e- ISSN: 2319-8753, p-ISSN: 2347-6710.

[12] SuchitaTuppad and Fernades R J, “Optimum location of shear wall in a multi-storey building subjected to seismic behaviour using genetic algorithm", International Research Journal of Engineering and Technology (IRJET), Volume: 02, Issue: 04, 2015, pp. 236- 240, eISSN: 295-0056, p-ISSN: 2395-0072.

[13] MohdAtif, LaxmikantVairagade and Vikrant Nair, "Comparative study on seismic analysis of multi-storey building stiffened with bracing and shear wall", International Research Journal of Engineering and Technology (IRJET), Volume: 02, Issue: 05, 2015, pp. 1158- 1170, e-ISSN: 2395-0056, p-ISSN: 2395-0072.

[14] Rohit Kumar Singh, VivekGarg, Abhay Sharma, "Analysis and design of concrete diagrid building and its comparison", International Journal of Science, Engineering and Technology (IJSET), Volume: 02, Issue; 06, August 2014, pp. 1330-1337, ISSN: 2348-4098.

[15] Sanjay Sengupta "Study of shear walls in multi-storied buildings with different thickness and reinforcement percentage for all seismic zones in India”, International Journal of Research in Engineering and Technology (IJRET), Volume: 03, Issue: 11, November 2014,pp. $197-$ 204, e-ISSN: 2319-1163, p-ISSN: 2321-7308.

[16] Nishith B Panchal and Vinubhai R Patel, "Diagrid structural system: strategies to reduce lateral forces on high-rise buildings", International Journal of Research in Engineering and Technology (IJRET), Volume: 03, Issue: 04, April 2014, pp. 374-378.

[17] Nitin Choudhry and MahendraWadia, "Pushover analysis of RC framed building with shear wall", IOSR Journal of Mechanical and Civil Engineering (IOSR-JMCE), Volume: 11, Issue: 02, March-April 2014, pp.09-13, eISSN: 2278-1684, p- ISSN: 2320-334X.

[18] Giovanni Maria Montuori, Elena Mele, Giuseppe Brandonisio and Antonello De Luca, "Geometrical patterns for diagrid buildings: exploring alternative design strategies from the structural point of view", Engineering Structure 71, 2014, pp. 112-127.

[19] Mr. Dharmesh Dhabliya, Dr.S.A.Sivakumar. (2019). Analysis and Design of Universal Shift Register Using Pulsed Latches . International Journal of New Practices in Management and Engineering, 8(03), 10 - 16

[20] SepidehKorsavi, and Mohammad Reza Maqhareh, "The evolutionary process of diagrid structure towards architectural", Architectural Engineering Technology (JArchitEng Tech), Volume: 03, Issue: 02, 2014, pp.111.

[21] KhushbuJania and Paresh V Patel, "Analysis and design of diagrid structural system for high rise steel building", Chemical, Civil and Mechanical Engineering Tracks of 3rd Nirma University International Conference on Engineering (NUICONE), 2013, pp. 92-100. 